\title{
Activity pattern and habitat association of Assamese macaques Macaca assamensis McClelland, 1840 in Shivapuri Nagarjun National Park, Nepal
}

\author{
Kalpana Ghimire ${ }^{1}$ (D) I Mukesh Kumar Chalise ${ }^{2 *}$ (D) \\ ${ }^{1}$ Central Department of Environmental Science, Tribhuvan University, Kathmandu, Nepal \\ ${ }^{2}$ Nepal Biodiversity Research Society, Lalitpur, Nepal \\ * Correspondence: mukesh57@hotmail.com
}

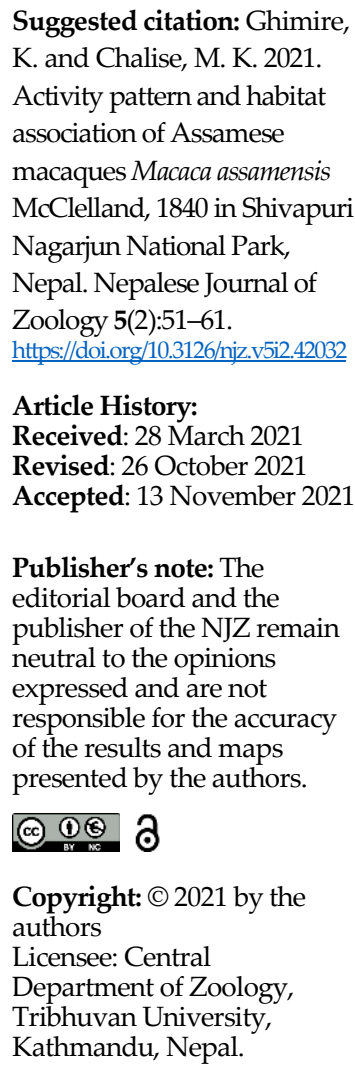

Assamese macaque Macaca assamensis McClelland, 1840 is one of the least studied primate species (Chalise 2008). It belongs to the sinica-group of macaques based on the male genitalia, sagittate and subacute glans in the dorsal view (Fooden 1976). Assamese macaque population of Nepal varies from India and Bhutan with differences in various aspects such as tail length, elevation wise distribution, facial colour and pelage to very close conspecific populations of Macaca assamensis pelops sampling, Nagarjun

\begin{abstract}
Assamese macaque Macaca assamensis McClelland, 1840 is one of the primate species with narrow distribution range and the least exploration. This study investigated the diurnal activity of Assamese macaque and association with the vegetation in Nagarjun Forest of Shivapuri Nagarjun National Park, Nepal. Behaviour sampling including Instantaneous sampling and Ad-libitum sampling (7:30 AM - 4:30 PM) along with vegetation survey (20 $\mathrm{m} \times 20 \mathrm{~m}$ plots) were applied. The Raniban Barrack troop of Assamese macaque composed of 12 individuals was observed for a total of 225 hours to record the macaque's diurnal activity. The troop spent $28 \%$ time in inactive, $25 \%$ in grooming, $23 \%$ in foraging, $23 \%$ in locomotion and $1 \%$ in fighting. Assamese macaque troop spent more time in Schima wallichii possessing $25.91 \%, 36.29 \%$ and $41.22 \%$ for foraging, locomotion and inactive respectively of the diurnal time. Altogether, 67 plant species (herbs, shrubs, trees and climbers) were documented from vegetation analysis. Schima wallichii and Ardisia macrocarpa were dominated the habitat. Paired t-test revealed significant difference in foraging ( $\mathrm{df}=24, \mathrm{P}=0.010)$ and inactive $(\mathrm{df}=24, \mathrm{P}=0.003)$ between the morning and day observational phases. The findings of this study shed light on the food preference and microhabitat use by the protected Assamese macaque in Nepal that assists to formulate the management plans for the species.
\end{abstract}

Keywords: Ad libitum sampling, Diurnal activity, Habitat association, Instantaneous

\section{I Introduction}

(Molur et al. 2003). Therefore, Assamese macaque in Nepal was doubted to be of distinct subspecies status and inferred as "Macaca assamensis Nepalese population" warranting further study on the taxonomy (Boonratana et al. 2020). Due to such unique characters of "Macaca assamensis Nepalese population" it is considered likely endemic to Nepal (CAMP 2003). Recent phylogenetic study using multiple mitochondrial and nuclear gene sequences suggested a distinct species status of the population (Khanal et al. 2021). 
Due to the small population size, restricted distribution and its fragmented habitats the Assamese macaque is protected by Department of National Parks and Wildlife Conservation Act, 1973 of Nepal (Chalise 2013; Chalise et al. 2013). It is listed as Near Threatened in the IUCN Red List of Threatened Species (Boonratana et al. 2020) and is included in CITES Appendix II (CITES 2012). The species has a limited distribution in Nepal, India, Bhutan, northern Myanmar, northern Thailand (Chalise 1999) and southern China (Zhang et al. 1981). Assamese macaque in Nepal was recorded from $160 \mathrm{~m}-2,650 \mathrm{~m}$ covering the narrow elevational range of mid hills basically in sub-tropical regions (Chalise 2013; Khanal et al. 2019). The details regarding its socio-ecology are yet to be explored (Khanal et al. 2018). Various macaque troops are recorded even from the farwestern Nepal, around $300 \mathrm{~km}$ west of the previously known range (Khanal et al. 2019).

Assamese macaques favour to reside in the subtropical evergreen and the deciduous forest on a high elevation (Srivastav \& Mohnot 2001). The major food sources of the macaques are Schima wallichii and Castanopsis spp. in Shivapuri Nagarjun National Park (Chalise 1999). Besides leaf, the other foods which are consumed by the macaques are invertebrates, mushroom and mosses (Pandey \& Chalise 2016). The aggressive nature was recorded for the long time when there was provisioned food supplied for the macaques (Mitra 2002).

In Shivapuri Nagarjun National Park, Assamese macaque troop allocates most of their time in foraging while that of least in playing (Chalise et al. 2015). In Raniban and Fulbari Gate, the macaque troop forage during day and stay night in the cliffs and initiate their daily activities in the next day (Chalise et al. 2013). In winter season grooming and playing activities are less common (Pandey \& Chalise 2016). Assamese macaques form multimale and multi-female social troops (Molur et al. 2003). They quarrel less with the member of Rhesus troops. In order to aware the troops about the possible threats to their territory a very high- pitched voice is usually common in them (Chalise 2003).

There are numerous factors that may affect the activity pattern of Assamese macaques. The range size and the habitat utilization of Assamese macaques impacted by the distribution and availability of the food can seriously influence on their activity (Zhou et al. 2014). Apart from this, the intrinsic factor such as temperature can contribute to the development of the stereotypic behaviour in the primates. Several environmental factors such as humidity, precipitation and cloudy environment can create serious effects on the basic activity pattern in primates and making them able to adapt in the environmental variations through the resting activity (Erkert \& Grfber 1986).

Since Assamese macaque is the least studied primate species study regarding the activity pattern of Assamese macaques is very crucial in the conservation action. Thus, this study can be of great importance to assist in setting of the species management plans and prevention of future decline of the species for the long term. The study was carried to know the diurnal activity pattern and habitat association of Assamese macaque troop by behaviour sampling and the vegetation analysis.

\section{2 | Materials and methods}

\subsection{Study area}

Shivapuri Nagarjun National Park encompasses an area of 159 square kilometers after the inclusion of 15 square kilometers of Nagarjun forest in 2009 covering the various districts such as Kathmandu, Sindhupalchowk, Nuwakot and Dhading (Pandey 2010). Its elevation ranges between $1350-2100 \mathrm{~m}$. The mean monthly precipitation of this national park ranges from $3.43-444.56 \mathrm{~mm}$ while the mean monthly temperature is from $3.9^{\circ} \mathrm{C}-20.4^{\circ} \mathrm{C}$ (minimum) and $18.6{ }^{\circ} \mathrm{C}-29.6{ }^{\circ} \mathrm{C}$ of the maximum temperature (Koirala \& Chalise 2014). 


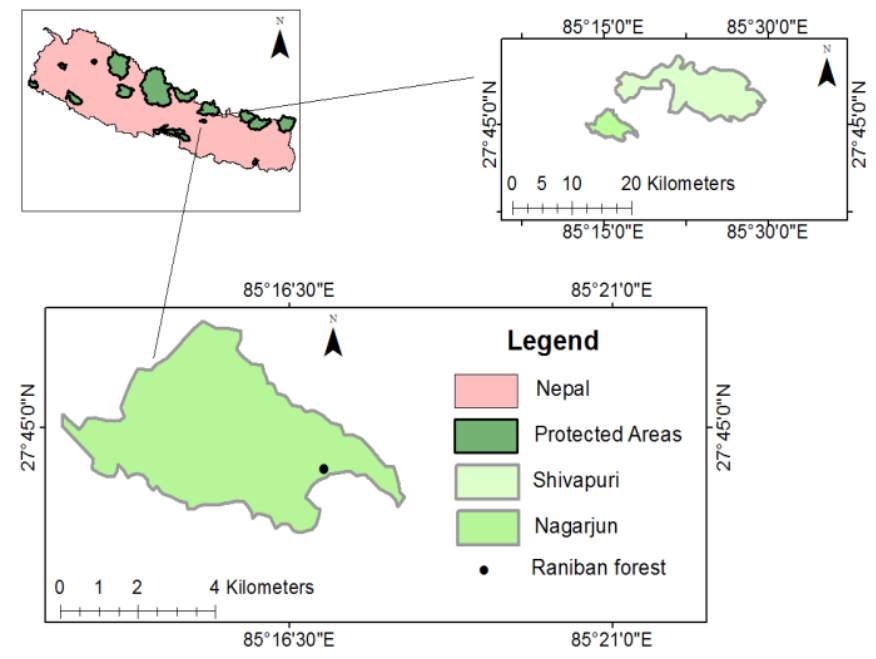

Figure 1. Location map of Raniban Forest, Shivapuri Nagarjun National Park, Nepal

Raniban Forest, Nagarjun of Shivapuri Nagarjun National Park was chosen for the study which comprises four types of vegetation viz. Schima wallichii forest, pine forest, dry oak forest and mixed broadleaf forest. Shivapuri Nagarjun National Park possess various mammals such as Clouded leopard (Pardofelis nebulosa), Himalayan black bear (Ursus thibetanus), Common leopard (Panthera pardus), Pangolin (Manis spp.) as protected by the National Parks and Wildlife Conservation Act, 1973 (Pandey \& Chalise 2016). It is only the best habitat for Himalayan Dragonfly (Epiophlebia laidlawi) in Nepal (Tani \& Miyatake 1979; Mahato 1993).

\section{2 | Field survey}

To detect the likely areas of macaque troop presence and its selection for the study preliminary survey was carried out during 19th-28th February, 2019. Total 6 transects were surveyed within $3 \mathrm{~km}$ from Fulbari Gate to Raniban on either side of the forest trail. Areas where the macaque troops encountered was considered as "focal areas" firstly. Two troops of the macaques were encountered. Among two troops Raniban Barrack Troop A and Raniban premises troop B encountered, Raniban Barrack Troop-A was selected for behavioural observations. Basically, two categories were chosen for selecting the macaque troops for the study. The categories included site feasibility in terms of terrain and the age of macaque's troop following the method of Chalise (2003) which included infants, sub-adult (males and females), adult (males and females).

Population census of the Assamese macaque troop was performed and age-sex classification was done following Chalise (2008). Two observers were involved from 20th to 23rd February, 2019 to count the head of macaques for nine hours. Individual counting and its troop identification in one observation phase were reciprocated for multiplex times to ensure the data accuracy. Each individual macaque's head of Raniban Barrack troop A was counted with the binocular aid.

\section{3 | Behaviour sampling}

Initially, the macaque troop was identified by observing the specific identifying characters such as their body size and colour, markings on the body and the behaviour they reflect. For the study Raniban Barrack troop A was habituated first and then only adult males and females were taken into account. Total five adult males and female individuals were chosen to record the behaviour. In accordance to Altmann (1974) instantaneous sampling was carried out which included foraging, locomotion, inactive (resting, sleeping and sitting), grooming and fighting behavioural states. The macaque troop behaviour was recorded continuously for two minutes in each interval of 15 minutes. The total instantaneous sampling was carried for nine hours from 7:30 AM - 4:30 PM per day dated 17th March - 21st May, 2019. Ad-libitum sampling was carried following the method of Altmann (1974). This sampling was carried from 7:30 AM - 4:30 PM dated 17th March - 21st May, 2019. Foraging, locomotion, inactive, grooming and fighting were the behaviours observed to study the activity pattern of Assamese macaque troop (Table 1).

\section{4 | Vegetation survey}

The purposive random sampling was carried for the vegetation analysis in the site covering all the four directions (East, West, North and South). Altogether, fifteen random plots having size of 20 
Table 1. The ethogram used to record behavior of Assamese macaques

\begin{tabular}{|c|c|c|}
\hline S.N. & Activity & Description \\
\hline 1. & Foraging & Wandering from here to there in search of food and consuming food or drinking water. \\
\hline 2. & Locomotion & Movement from one location to other. \\
\hline 3. & Inactive & $\begin{array}{l}\text { Condition of resting, inhabiting and sleeping attached either to the tree or other supporting } \\
\text { surfaces/position of lying on the ground and trees, stretched legs. }\end{array}$ \\
\hline 4. & Grooming & $\begin{array}{l}\text { Searching for their own fur or other macaque's body fur for lice, ticks, fleas and bugs/activity } \\
\text { of rubbing or scratching. }\end{array}$ \\
\hline 5. & Fighting & $\begin{array}{l}\text { Expression of aggressive nature to each other by bare teeth, slapping or making noise which } \\
\text { occurs mostly in groups. }\end{array}$ \\
\hline
\end{tabular}

$\mathrm{m} \times 20 \mathrm{~m}$ following the method of Abunie and Dalle (2018) were established with threads, pegs and the measuring tape. The GPS locations of each of the four corner points of the established plots were recorded. The various life forms of flora which lied inside the plots were noted with tree $\mathrm{DBH}>10 \mathrm{~cm}$ with the help of DBH tape. Besides these, the dominant plant species were recorded in each plot. The prepared herbarium having fixed size $(42 \mathrm{~cm} \times 28 \mathrm{~cm})$ was identified in National Herbarium and Plant Laboratories, Godawari, Lalitpur, Nepal.

\section{5 | Data analysis}

The data was analysed by Karl Pearson Correlation Coefficient to know the relationship between behavioural states using $\mathrm{R}$ software. All the statistical tests were considered significant at $\mathrm{P}$

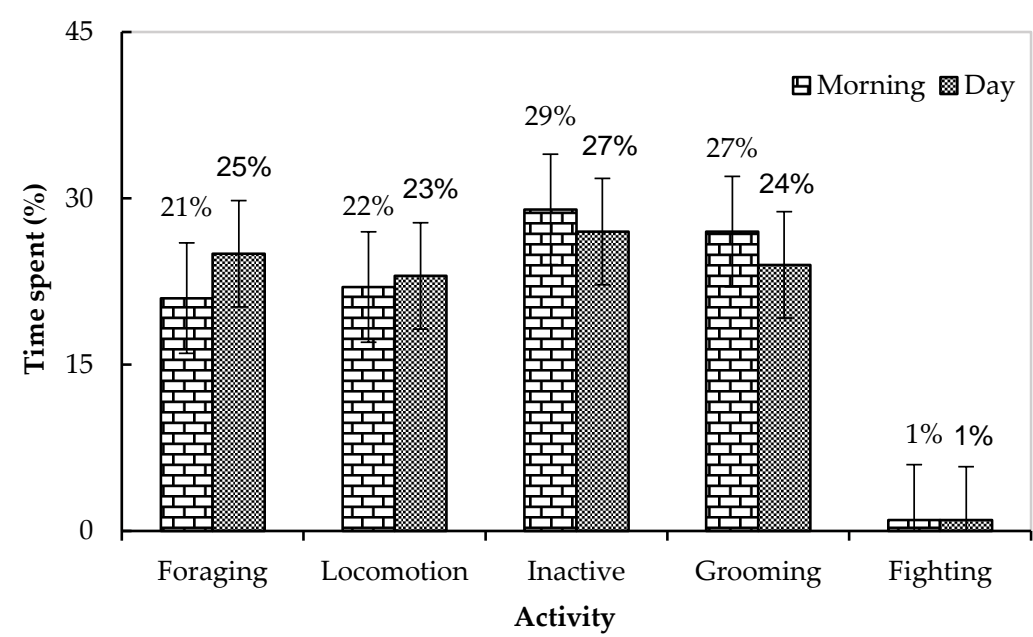

Figure 2. Time spent (\%) by the macaque troop in Raniban Forest during morning and day value $<0.05$. The numerous variables used for determining the correlation between the macaque troop activity were foraging, locomotion, inactive and grooming. Paired t-test was used to seek the significant difference between the variables (behaviour) of the macaque troop between morning and day using $\mathrm{R}$ software.

The overall activity of Assamese macaque troop was determined using below formula:

$$
\begin{aligned}
& \text { Activity }=\frac{\text { Number of behavior records for each activity }}{\text { Number of behavior records for all activities }} \times 100 \% \\
& \text { Sex ratio }=\frac{\text { Total number of males of that age group }}{\text { Total number of females of the same age group }} \\
& \text { Adult Sex ratio }=\frac{\text { Total number of adult males of that age group }}{\text { Total number of adult females of same age group }} \\
& \text { Food items }=\frac{\text { Total number of individual item consumed }}{\text { Total number of food items consumed }} \times 100 \%
\end{aligned}
$$

\section{3 | Results}

Total two troops of Assamese macaques were encountered from Fulbari Gate to Raniban. The first troop (Raniban barrack troop A) consisted 12 individuals and the second one (Raniban premises troop B) consisted 19 individuals. The sex ratio of male to female in Raniban Barrack troop A was recorded 1:1.4 while adult male to adult female ratio was found 1:1.5. Females comprised higher percentage $(58.33 \%)$ than that of males $(41.66 \%)$. In relation to the age composition, infant and adult females possessed the highest 


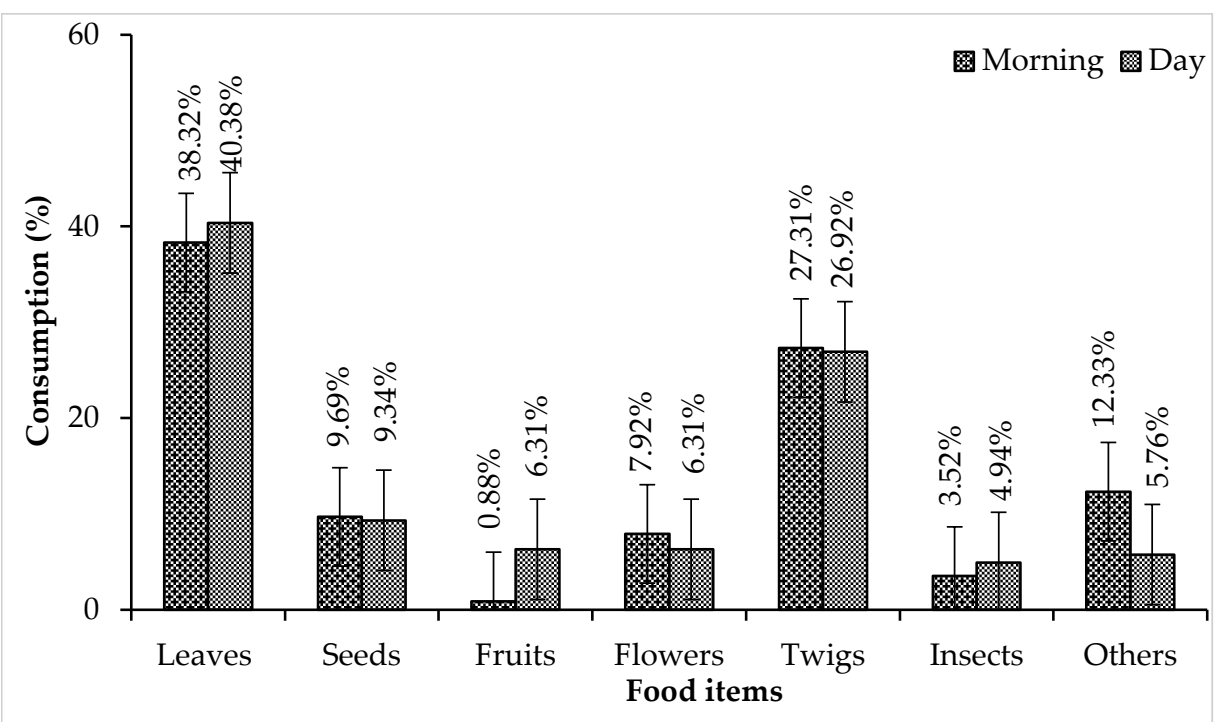

Figure 3. Food items (\%) consumed by the macaque troop during morning and day
Food items categorized as leaves, seeds, fruits, flowers, twigs, insects and others (leftover rice, vegetables) were consumed by the troop. Leaf consumption was the highest in both morning and the day time (Fig. 3).

During the morning, the troop spent highest time in Schima wallichii tree, and for foraging $(27.61 \%)$, locomotion $(36.76 \%)$ and inactive $(46.19 \%$, resting sleepin$\mathrm{g} /$ sitting). The macaque percentage (both $25 \%$ ) and lowest in the sub-adult male and female (both $8.33 \%$ ). During the study period the macaque population of Raniban Barrack troop A was increased since two adult female macaques had given birth to one male and one female infant during April (the breeding season).

For the behavioural study, Raniban Barrack troop A was selected and behaviour was observed for a total of 225 hours. Five adult males and females from Raniban Barrack troop A spent $29 \%$ of their time in inactive (highest) and $1 \%$ in fighting (lowest) during morning. Likewise, $27 \%$ of the troop activity was inactive (highest) and 1\% was fighting (lowest) during day (Fig. 2).

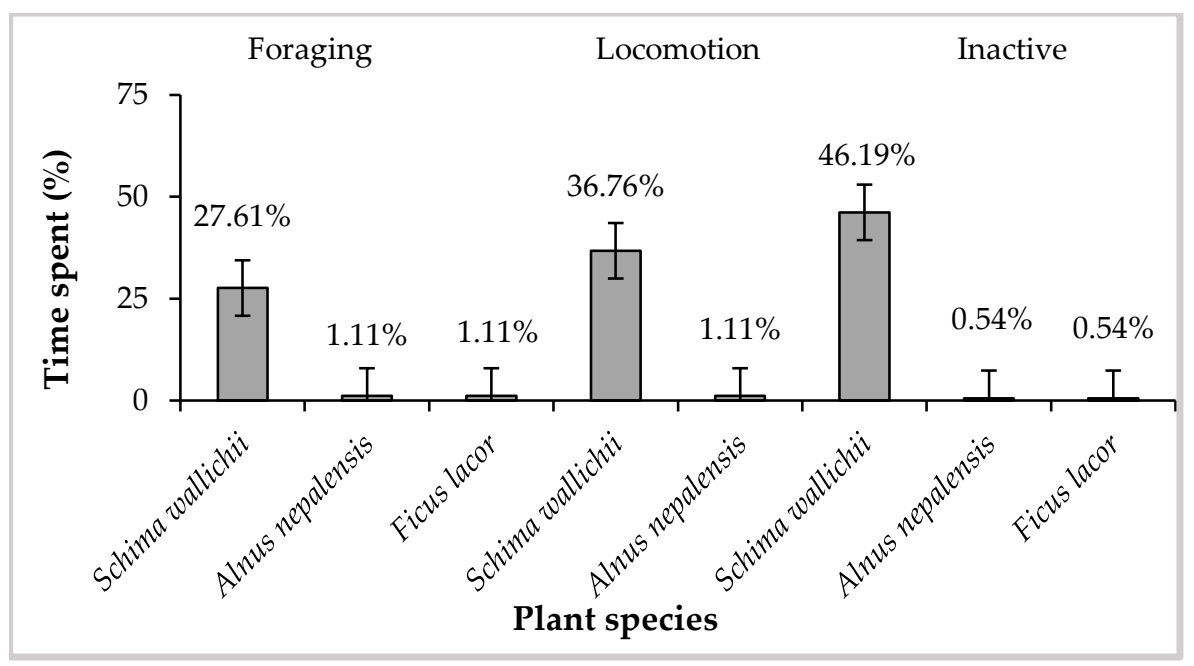

Figure 4. Highest and lowest time spent (\%) in plant species by the macaque troop during morning troop spent lowest time in Alnus nepalensis and Ficus lacor for foraging, locomotion and inactive (Fig. 4).

For foraging, locomotion and inactive during day Raniban Barrack troop A spent highest time in Schima wallichii $(24.21 \%),(35.82 \%)$, and $(36.26 \%)$ respectively (Fig. 5). Likewise, the macaque troop spent lowest time in Myrica esculenta for foraging, locomotion and inactive (resting/sleeping/sitting).

Various behaviours of Assamese macaque troop were tested by Shapiro-Wilk Normality test to test whether the data is normally distributed. The normality test revealed the normal distribution of data. Thus, Karl Pearson Correlation Coefficient considering variables such as foraging, locomotion, inactive and grooming was used (Table 2). It was applied to determine the strength of relationship between two or more than two variables and seeking how close the relationships are, whether one variable have impact on other variable in the macaque troop activity. Beside this, the significant 


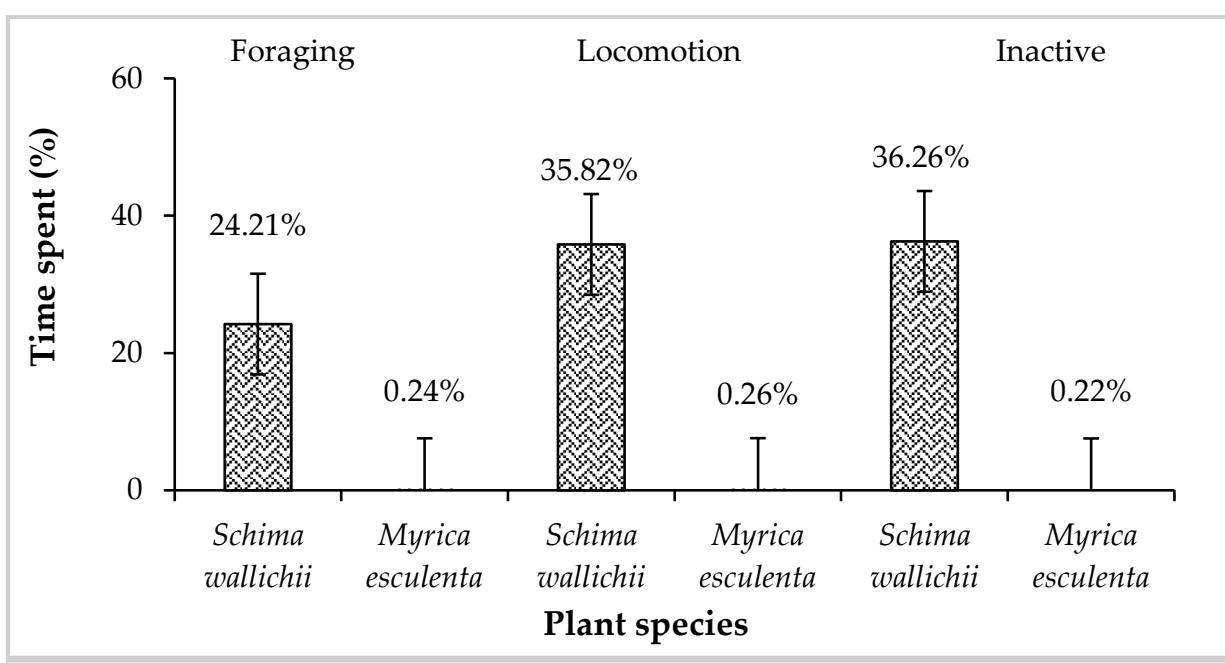

Figure 5. Highest and lowest time spent (\%) in plant species by the macaque troop during day

difference in the macaque troop activity between morning and day observation phases was tested by paired t-test. From the vegetation analysis following plant species were recorded with the inclusion of their biological names, families and the life forms (Supplementary Table 1).

\section{4 | Discussion}

This study recorded female biased sex ratio in the Assamese macaques of Nagarjun Forest. Chalise et al. (2013) also recorded less male population than female in Raniban Forest of Shivapuri Nagarjun National Park which likely supports with our findings since we recorded less male population in Raniban Barrack troop A than the females.

\subsection{Assamese macaques' activity during morning}

In our study, Assamese macaque troop in Raniban Forest spent $21 \%$ in foraging during the morning which is dissimilar to the findings of Chalise (2010) and Ghimire (2017). Locomotion alone accounted for $22 \%$ of their time which likely supports with our findings of Chalise (2010) and (Koirala \& Chalise 2014) with 22\%. Foraging by macaque troop may be less because of low consumption of the young leaves and fruits since young leaves possess phenolic compounds such as non-protein amino acids and alkaloids during early spring. The detoxification systems in most of the primates cannot handle the phenolic compounds which the plants use (Glander 1982). The study of Wrangham and Waterman (1981) revealed the effects of plant phenolic compounds on the food selection of the primates in Amboseli National Park, Kenya.

Twenty-nine percentage of the time, the macaques were inactive (resting, sleeping and sitting). This study contrasted to the findings of Ghimire (2017) in Nagarjun forest with 19\%. Delgado et al. (2004) implied that the macaque troop spend their time in resting to avoid the sun-exposure in hot days. The sunrise time may influence highly in the activity pattern of monkeys. Moreover, the study of Pandey and Chalise (2016) insisted that the species is the lazy primate that allocates about $14.95 \%$ for sun basking and resting. They sleep and rest during early morning and the sun basks period which finds similarity to our findings that the macaque troop spent highest percentage of time in resting. Grooming accounted for $27 \%$ of the time during morning in our study. Grooming indicates the good social communication among the troop members (Cooper \& Bernstein 2000). The macaque troop was recorded $1 \%$ in fighting. It may be due to the plenty of the food resources available in

Table 2. Correlation coefficient matrix between the behavioral states

\begin{tabular}{|c|c|c|c|c|c|}
\hline \multirow{5}{*}{ } & & Foraging & Locomotion & Inactive & Grooming \\
\hline & Foraging & 1 & & & \\
\hline & Locomotion & 0.23 & 1 & & \\
\hline & Inactive & -0.66 & -0.42 & 1 & \\
\hline & Grooming & -0.76 & -0.59 & 0.31 & 1 \\
\hline \multirow{4}{*}{$\stackrel{\vec{ే}}{0}$} & Foraging & 1 & & & \\
\hline & Locomotion & -0.08 & 1 & & \\
\hline & Inactive & -0.74 & -0.33 & 1 & \\
\hline & Grooming & -0.58 & -0.65 & 0.80 & 1 \\
\hline
\end{tabular}


Raniban Forest. Thus, the macaques may have less competition for the food resources.

\subsection{Assamese macaques' activity during day}

The foraging of the macaque troop alone accounted for $26 \%$ during day. The study of Koirala and Chalise (2014) depicted that the foraging time of Assamese macaque troop was recorded highest (46\%) during 12 noon to $15 \mathrm{pm}$ and that of lowest during $15 \mathrm{pm}$ to $18 \mathrm{pm}$ in Shivapuri Nagarjun National Park. Our study supported the same findings that foraging was highest during the day time. Boonratana et al. (2008) revealed that it spends most of the diurnal time in feeding since they are omnivorous in nature. In the early morning, the Assamese macaques feed on leaf as their main food possibly due to hunger. In the late noon they search for the food they want (Pandey \& Chalise 2016). Among 67 plant species recorded in Raniban, 11 tree species and one climber species (Hedera helix) were frequently consumed by Raniban Barrack macaque troop A.

The troop spent $23 \%$ of their time in locomotion, $27 \%$ in inactive and $24 \%$ in grooming during the day. Grooming was less in Langtang National Park with $9-13 \%$ (Chalise 1999) and $12-20 \%$ in MakaluBarun National Park (Chalise 2003). Chalise and Adhikari (2014) revealed that the macaque troop usually invests low time in grooming which reflects vast difference with our findings. The macaque troop removes the various parasites such as fleas, bugs and ticks from their body either by self-grooming or grooming with their partners (Cooper \& Bernstein 2000). In addition, grooming can provide relaxation to the primates and reduce the tension (Terry 1970). Raniban Barrack troop A spent $1 \%$ of the time in fighting during day. Since the fighting percentage seems very less, it reflects the mutual cooperation between the troop members in Raniban Forest.

\subsection{Relation between the macaque troop activity and its habitat}

Vegetation analysis is very crucial during the study of the primate's behaviour since it provides crucial idea on the species composition and structure of the plant community in the macaques habitat. Raniban Barrack troop A carried most of its activity such as foraging, locomotion and inactive in Schima wallichii (March-May season). The troop consumed higher percentage of leaves. Milton (1987) insisted that the wild primates basically consume the high proportion of their daily diet from the plant items such as leaves, fruits and flowers which is similar to our study that the macaque troop fed highest on the leaves.

The activity of Assamese macaque is directly attached to its habitat. The more is the food availability; the more time macaque can do rest. Assamese macaque troop may have spent their huge time in Schima wallichii since there was record of Schima wallichii as dominant tree by the field observation. Most of the primate species resides in social troops in its habitat which may create the intragroup feeding competition among them (Lambert 2012). But during our study most of the troop members locomoted and took rest in Schima wallichii tree where there was no any intragroup competition. Because there was huge availability of the food resources in their habitat and have more time to rest.

Milton (1979) revealed that the wild primates such as howler monkey satisfies their diet through consumption of the leaves and fruits which provides them daily protein and the high energy. Many primates have the record of consuming the leaves, fruits and flowers of the forest trees (Milton 1987) on each day (Trevathan 1987) which finds similarity with our findings. Plant protein seems to be adequate in daily protein requirements for the primate's diet (Milton 1999). They mostly prefer plant items despite of availability of animal items in the forest which reveals similarity to our findings that Raniban Barrack troop A consumed the leaves as the major plant items in comparison to the animal items. 
The positive correlation between foraging and locomotion (0.23), inactive and grooming (0.31) during morning lamented that the activity carried by Macaca assamensis troop had great influence on each other. When the foraging increases locomotion too increases in the macaque troop. The positive correlation between inactive and grooming ( 0.31 during morning and 0.80 during day) indicates that once the macaque troop are full of diet they may spent their time in resting and may groom each other to take care and maintain the troop relations stronger. In between other activity the correlation coefficient was recorded negative. Likewise, during day except between inactive and grooming (0.80) there was negative correlation between all activity which signifies that most of the variables don't depend and influence each other.

Paired t-test revealed that there was significant difference in foraging ( $\mathrm{df}=24, \mathrm{P}=0.010)$ and inactive $(\mathrm{df}=24, \mathrm{P}=0.003)$ between morning and day. Since $P$ values were less than 0.05 in $95 \%$ confidence interval there was significant difference. The foraging activity by the macaque troop during morning may be peak due to the food competition among the monkeys while afternoon peak may not be observed alike since the food distribution for the macaques may be restricted from 9:00 am-12:00 pm (Delgado et al. 2004). In our study too the foraging was peak during morning than the day which may have resulted significant difference in foraging. There was no significant difference in locomotion ( $\mathrm{df}=24, \mathrm{P}=0.383$ ), grooming $(\mathrm{df}=24, \mathrm{P}=0.158)$ and fighting $(\mathrm{df}=3, \mathrm{P}$ $=0.296$ ) in between morning and day. This implies that once the macaque troop consume enough food for them they may spent their time in other activity such as grooming which may have resulted no significant difference of the diurnal time.

Schima wallichii and Ardisia macrocarpa were recorded dominant by field observation among total 67 plant species (herbs, shrubs, trees and climbers) documented in various established plots in Raniban Forest. But the research implied by Ghimire (2017) documented only 52 plant species possessing Schima wallichii as the dominant tree in
Nagarjun forest. During our study the highest dBH was of Bombax ceiba with $106 \mathrm{~cm}$. Among the different life forms, trees were recorded highest (34 species) followed by the herbs (14 species), shrubs (13 species) and the climbers (6 species). Around $55 \%$ of Raniban Forest was recorded invaded by field observation by the invasive plant species namely Eupatorium adenophorum, Lantana camara and Parthenium hysterophorus which affects the habitat of the macaque troop thereby restricting the proper growth and development of other plant species.

Further research in other parts of Nagarjun is foremost since whole Nagarjun (15 sq. km.) is crucial habitat for Macaca assamensis. Beside this, plantation of Alnus nepalensis and Myrica esculenta is also recommended in the macaques habitat for the higher availability of their food resources in Raniban Forest.

\section{5 | Conclusions}

Altogether 900 events of Raniban Barrack troop A were recorded. The major activities carried by macaque troop during the study period (MarchMay) in Raniban Forest were foraging, locomotion, inactive (resting, sleeping and sitting) and grooming. Among the major activities inactive was recorded highest during morning (7:30 am-11:30 am) and day (11:30 am-4:30 pm) followed by grooming and foraging. Fighting was very less. Furthermore, the troop spent more time in Schima wallichii possessing $25.91 \%, 36.29 \%$ and $41.22 \%$ for foraging, locomotion and inactive respectively of the diurnal time. There was positive correlation between foraging and locomotion, inactive and grooming during morning. Likewise, negative correlation was recorded between other activity during day except for inactive and grooming. In total, 67 plant species were documented indicating higher species diversity in Raniban Forest dominated by Schima wallichii and Ardisia macrocarpa. Plant species invasion was the major threat in the macaque habitat in Raniban Forest. 


\section{Acknowledgements}

Thanks to Department of National Parks and Wildlife Conservation, Shivapuri Nagarjun National Park and Nagarjun sector for granting us permission to undertake this research. We would like to acknowledge National Herbarium and Plant Laboratories, Lalitpur for assisting us in identification of the prepared herbarium.

\section{Authors' contributions}

Ghimire, K. carried the field work and prepared the manuscript. Chalise, M. K. designed and supervised the work. Both authors contributed in preparing the final manuscript and approved for the submission.

\section{Conflicts of interest}

Authors declare no conflict of interest.

\section{ORCID}

Kalpana Ghimire: https://orcid.org/0000-0003-3673-720X.

Mukesh Kumar Chalise: https://orcid.org/0000-0002-1417-6053

\section{References}

Abunie, A. A. and Dalle, G. 2018. Woody species diversity, structure, and regeneration status of Yemrehane Kirstos Church forest of Lasta Woreda, Ethiopia. International Journal of Forestry Research 2018:1-8.

Altmann, J. 1974. Observational Study of Behavior: Sampling Methods. Behavior 49:227-267.

Boonratana, R., Chalise, M. K., Das, J., Htun, S. and Timmins, R. J. 2008. Macaca assamensis. The IUCN Red List of Threatened Species 2008:e. T12549A3354977.

Boonratana, R., Chalise, M. K., Das, J., Htun, S. and Timmins, R. J. 2020. The IUCN Red List of Threatened Species. https://www.iucn.org/themeLspecies/our-work/iucn-red-list-threatenedspecies. Accessed on 12 June 2021.

Chalise, M. K. 1999. Report on the Assamese monkeys (Macaca assamensis) of Nepal. Asian Primates 7:711 .
Chalise, M. K. 2003. Assamese macaques (Macaca assamensis) in Nepal. Primate Conservation 19:99107.

Chalise, M. K. 2008. Primate census in Kathmandu and west parts of Nepal. Journal of Natural History Museum 23:60-64.

Chalise, M. K. 2010. A study of Assamese monkey in Sebrubeshi of Langtang National Park, Nepal. Journal of Natural History Museum 25:54-61.

Chalise, M. K. 2013. Fragmented primate population of Nepal. In: Marsh, L. K. and Chapman, C. A. (Eds.) Primates in Fragments: Complexity and Resilience, New York. pp 329-356.

Chalise, M. K. and Adhikari, R. K. 2014. General behavior of Assamese monkey (Macaca assamensis McClelland, 1840) at upper Marsyangdi area, Lamjung, Nepal. Special Issue DNPWC. pp 84-93.

Chalise, M. K., Bhattarai, G. P. and Pandey, B. 2015. Ecology and behavior of Assamese monkeys in Shivapuri Nagarjun National Park, Nepal. Journal of Natural History Museum 27:12-24.

Chalise, M. K., Ogawa, H. and Pandey, B. 2013. Assamese monkeys in Nagarjun Forest of Shivapuri Nagarjun National Park, Nepal. Tribhuvan University Journal 28:181-190.

CITES. 2012. Convention on International Trade in Endangered Species of Wild Fauna and Flora. https://cites.org/eng. Accessed on 14 May 2021.

Cooper, M. A. and Bernstein, I. S. 2000. Social Grooming in Assamese Macaques (Macaca assamensis). American Journal of Primatology 50:77-85.

Delgado, J. M., Corsi-Cabrera, M., Canales-Espinosa, D., Santillian-Doherty, A. M. and Erkert, H. G. 2004. Astronomical and meteorological parameters and rest-activity rhythm in the Spider monkey Ateles geoffroyi. Physiology and Behavior 83:107-117.

Erkert, H. G. and Grfber, J. 1986. Direct modulation of activity and body temperature of owl monkeys (Aotus lemurinus griseimembra) by low light intensities. Folia Primatol 47:171-188.

Fooden, J. 1976. Provisional classification and key to living species of macaques (Primates: Macaca). Folia Primatologica 25:225-236.

Ghimire, A. 2017. Feeding behavior of sympatric Rhesus monkeys (Macaca mulatta Zimmerman, 1780) and Assamese monkeys (Macaca assamensis McClell- 
and, 1840) in Nagarjun forest, Shivapuri Nagarjun National park, Nepal. MSc Thesis, Tribhuvan University, Kirtipur, Kathmandu, Nepal.

Ghimire, K. 2019. Diurnal activity pattern of Assamese macaque (Macaca assamensis McClelland, 1840) in Nagarjun forest, Shivapuri Nagarjun National Park, Nepal. MSc Thesis, Tribhuvan University, Kirtipur, Kathmandu, Nepal.

Glander, K. E. 1982. The impact of Plant Secondary Compounds on Primate Feeding Behavior. Yearbook of physical anthropology 25:1-18.

Khanal, L., Chalise, M. K., He, K., Acharya, B. K., Kawamoto, Y. and Jiang, X. 2018. Mitochondrial DNA analyses and ecological niche modeling reveal post-LGM expansion of the Assam macaque (Macaca assamensis) in the foothills of Nepal Himalaya. American Journal of Primatology 80:e22748.

Khanal, L., Chalise, M. K. and Jiang, X. L. 2019. Distribution of the threatened Assamese macaque Macaca assamensis (Mammalia: Primates: Cercopithecidae) population in Nepal. Journal of Threatened Taxa 11:13047-13057.

Khanal, L., Chalise, M. K., Fan, P. F., Kyes, R. C. and Jiang, X. L. 2021. Multilocus phylogeny suggests a distinct species status for the Nepal population of Assam macaques (Macaca assamensis): implications for evolution and conservation. Zoological Research 42(1):3-13.

Koirala, S. and Chalise, M. K. 2014. Feeding ecology of Assamese macaque (Macaca assamensis) in Nagarjun Forest of Shivapuri Nagarjun National Park, Nepal. Nepalese Journal of Zoology 2:31-38.

Lambert, J. E. 2012. Primates in Communities: The Ecology of Competitive, Predatory, Parasitic and Mutualistic Interactions between Primates and Other species. Biological Anthropology 3:85.

Mahato, M. 1993. Epiophlebia laidlawi, a living ghost. Selysia 22:2.

Milton, K. 1979. Factors influencing leaf choice by howler monkeys: a test of some hypotheses of food selection by generalist herbivores. The American Naturalist 114:362-378.

Milton, K. 1987. Primate diets and gut morphology: implications for human evolution. In: Harris, M. and Ross, E. B. (Eds.) Food and evolution: toward a theory of human food habits.
Milton, K. 1999. Nutritional characteristics of Wild Primate Foods: Do the diets of our closest living relatives have lessons for us? Nutrition 1:488-498.

Mitra, S. 2002. Diet and feeding behavior of Macaca assamensis. Asian Primates 8:12-14.

Molur, S., Jones, D. B., Dittus, W., Eudey, A., Kumar, A., Singh, M. et al. 2003. Status of South Asian Primates: Conservation Assessment and Management Plan (C.A.M. P.) A report published by Zoo Outreach Organization and Conservation Breeding Specialist Group-South Asia, Coimbatore, India.

Pandey, B. P. 2010. Presence absence survey of clouded leopard (Neofelis nebulosa) in Shivapuri Nagarjun National Park, Nepal. A report submitted to DNPWC, Kathmandu, Nepal.

Pandey, B. P. and Chalise, M. K. 2016. General ecology and time budgeting for Assamese monkey (Macaca assamensis) in Shivapuri Nagarjun National Park, Nepal. Special issue DNPWC 2072.

Srivastava, A. and Mohnot, S. M. 2001. Distribution, conservation status and priorities for primates in Northeast India. Environmental Information System Bulletin Wildlife Protected Areas 1:102108.

Tani, K. and Miyatake, Y. 1979. The discovery of Epiophlebia laidlawi Tillyard, 1921 in the Kathmandu Valley, Nepal. Odontologica 8:329332.

Terry, R. L. 1970. Primate grooming as a tension reduction mechanism. Journal of Psychology 76: 129-136.

Trevathan, W. 1987. The chimpanzees of Gombe: patterns of behavior. American Journal of Physical Anthropology 73:409-410.

Wrangham, R. W. and Watermann, P. G. 1981. Feeding behavior of vervet monkeys in Acacia tortilis and Acacia xanthophloea: with special reference to reproductive strategies and tannin production. Journal of Animal Ecology 50:715-731.

Zhang, Y. Z., Wang, S. and Quan, G. Q. 1981. On the geographical distribution of primates in China. Journal of Human Evolution 10:215-226.

Zhou, Q., Wei, H., Huang, Z., Krzton, A. and Huang, C. 2014. Ranging behavior and habitat use of the Assamese macaque (Macaca assamensis) in limestone habitats of Nonggang, China. Mammalia 78:171-176. 
Supplementary Table 1. Plant species recorded in the habitat of the study troop in Raniban Forest

\begin{tabular}{|c|c|c|c|}
\hline S.N. & Biological Names & Family & Life form \\
\hline 1. & Achyranthes bidentata Blume & Amaranthaceae & Shrub \\
\hline 2. & Actinodaphne sikkimensis & Lauraceae & Tree \\
\hline 3. & Albizia julibrissin Durazz. & Fabaceae & Tree \\
\hline 4. & Alnus nepalensis D. Don & Betulaceae & Tree \\
\hline 5. & Ardisia macrocarpa Wall. & Myrsinaceae & Shrub \\
\hline 6. & Artemisia indica Willd. & Asteraceae & Shrub \\
\hline 7. & Bauhinia variegate L. & Fabaceae & Tree \\
\hline 8. & Berberis aristata & Berberidaceae & Shrub \\
\hline 9. & Bombax ceiba $\mathrm{L}$. & Bombacaceae & Tree \\
\hline 10. & Carex baccans Nees & Poaceae & Herb \\
\hline 11. & Castanopsis indica (Roxb.) Miq. & Fagaceae & Tree \\
\hline 12. & Cestrum nocturnum & Solanaceae & Shrub \\
\hline 13. & Colebrookea oppositifolia Sm. & Verbenaceae & Shrub \\
\hline 14. & Craniotome furcata (Link) Kuntze & Lamiaceae & Herb \\
\hline 15. & Digitaria ciliaris (Retz.) Koeler & Poaceae & Herb \\
\hline 16. & Dioscorea deltoidea Wall. Ex Griseb. & Dioscoreaceae & Climber \\
\hline 17. & Drymaria cordata (L.) Willd. ex Roem. E Schult. & Caryophyllaceae & Herb \\
\hline 18. & Eupatorium adenophorum Spreng. & Asteraceae & Herb \\
\hline 19. & Ficus lacor Buch.-Ham. & Moraceae & Tree \\
\hline 20. & Ficus religiosa $L$. & Moraceae & Tree \\
\hline 21. & Hedera helix & Aaliaceae & Climber \\
\hline 22. & Hedera nepalensis K. Koch. & Araceae & Climber \\
\hline 23. & Justicia adhatoda L. & Acanthaceae & Shrub \\
\hline 24. & Lantana camera L. & Verbenaceae & Shrub \\
\hline 25. & Ligustrum indicum & Oleaceae & Shrub \\
\hline 26. & Lindera nacusua (D. Don) Merr. & Lauraceae & Tree \\
\hline 27. & Lindera nesiana & Lauraceae & Tree \\
\hline 28. & Litsea monopetala (Roxb.) Pers. & Lauraceae & Tree \\
\hline 29. & Lygodium japonicum & Lygodiaceae & Climber \\
\hline 30. & Macaranga pustulata & Euphorbiaceae & Tree \\
\hline 31. & Machilus duthieni King ex Hook .f. & Lauraceae & Tree \\
\hline 32. & Magnifera indica L. & Anacardiaceae & Tree \\
\hline 33. & Mahonia napaulensis DC. & Berberidaceae & Shrub \\
\hline 34. & Morus serrata & Moraceae & Tree \\
\hline 35. & Myrica esculenta Buch-Ham. ex D. Don & Myricaceae & Tree \\
\hline 36. & Myrsine capitellata Wall. & Myrsinaceae & Tree \\
\hline 37. & Oxalis corniculata $\mathrm{L}$. & Oxalidaceae & Herb \\
\hline 38. & Parthenium hysterophorus L. & Asteraceae & Shrub \\
\hline 39. & Pinus roxburghii Sarg. & Pinaceae & Tree \\
\hline 40. & Pogonatherum paniceum (Lam.) Hack & Poaceae & Herb \\
\hline 41. & Pogostemon benghalensis (Burm. f.) Kuntze & Lamiaceae & Shrub \\
\hline 42. & Prunus cerasoides D. Don & Rosaceae & Tree \\
\hline 43. & Pteris biaurita & Pteridaceae & Herb \\
\hline 44. & Randia dumetorum & Rubiaceae & Shrub \\
\hline 45. & Schima wallichii (DC.) Korth. & Theaceae & Tree \\
\hline 46. & Smilax aspera $\mathrm{L}$. & Smilaceae & Herb \\
\hline 47. & Solanum xanthocarpum Schrad. \& Wendl. & Solanaceae & Herb \\
\hline 48. & Tetrastigma serrulatum (Roxb.) Planch. & Vitaceae & Climber \\
\hline 49. & Teucrium quadrifarium & Lamiaceae & Herb \\
\hline 50. & Urtica dioica $\mathrm{L}$. & Urticaceae & Herb \\
\hline 51. & Zizyphus incurve Roxb. & Rhamnaceae & Tree \\
\hline 52 & Unidentified 16 plant species & & \\
\hline
\end{tabular}

